\title{
PERBEDAAN PENGARUH MODEL STUDENT TEAMS ACHIEVEMENT DIVISION (STAD) DAN NUMBERED HEADS TOGETHER (NHT) TERHADAP HASIL BELAJAR MATEMATIKA SISWA KELAS V SD
}

\author{
Nur Halimah, Sumardjono \\ 292013139@student.uksw.edu, sumardjonopm@staff.uksw.edu \\ PGSD UKSW Salatiga

\begin{abstract}
THE DIFFERENCE OF STUDENT TEAMS ACHIEVEMENT DIVISION (STAD) AND NUMBERED HEADS TOGETHER (NHT) MODEL INFLUENCE TO MATHEMATICS LEARNING OUTCOMES OF 5TH GRADE STUDENTS
\end{abstract}

\begin{abstract}
This study aimed to determine the significance of the influence differences between the use of Student Teams Achievement Division (STAD) model and Numbered Heads Together (NHT) model on the 5th grade students in mathematics learning outcomes. The type of research was a quasi experiment with an unpredictable Pretest Posttest design. The subjects of the study were students in school " $X$ " as experimental class 1, and students in school " $Y$ " as experiment class 2. The variables in this study consisted of independent variables, namely Student Teams Achievement Division (STAD) model, Numbered Heads Together (NHT) model and dependent variable was learning outcome. Data collection was done by test technique. The data analysis technique used T test with Independent T test Sample applied to posttest value. The result of $t$ test of posttest value of experiment group 1 and experiment group 2 showed that the value was in significance of $0,019^{<} 0,05$. As the significance showed $<0,05$, hence $\mathrm{Ho}$ was rejected and $\mathrm{Ha}$ was accepted with conclusion that there was significant difference between the models to the learning result. The significant difference outcomes was supported by the difference average of two research samples, where the average of learning outcomes with STAD was 77.89, while the average of learning outcomes with learning model was 85.53. This meant that the learning treatment with NHT model has different significant impact compared to the STAD learning model in mathematics learning outcomes of grade 5.
\end{abstract}

Keywords: Student Teams Achievement Division (STAD), Numbered Heads Together (NHT), Learning Outcomes, Mathematics

Article Info

Received date: 27 April $2017 \quad$ Revised date: 9 Mei $2017 \quad$ Accepted date: 18 September 2017

\section{PENDAHULUAN}

Rendahnya kemampuan siswa dalam menyelesaikan persoalan matematika merupakan hal yang berpengaruh pada rendahnya kualitas pembelajaran matematika. Pada umumnya proses pembelajaran yang dilakukan guru sering menggunakan metode konvensional, metode yang membuat siswa tidak gembira menghadapi pelajaran. Dalam hal ini siswa hanya diposisikan sebagai pendengar guru, sehingga siswa mengalami kebosanan dalam mengikuti proses pembelajaran tersebut. Penggunaan strategi pembelajaran sangat mempengaruhi proses pembelajaran dan berpengaruh pada hasil belajar siswa. Selain itu, kondisi siswa yang pasif dan tidak terkendali juga sangat mempengaruhi proses pembelajaran sehingga guru akan merasa gagal dalam mengondisikan kelas. 
Perbedaan Pengaruh Model Student Teams Achievement Division (STAD) Dan Numbered Heads Together (NHT) Terhadap Hasil Belajar Matematika Siswa Kelas V SD (Nur Halimah, Sumardjono)

Oleh karena itu, untuk meningkatkan kualitas pendidikan khususnya pada pembelajaran matematika perlu adanya suasana belajar yang akan membuat siswa aktif, misalnya dengan memilih strategi pembelajaran yang sesuai dengan materi pembelajaran yang akan disampaikan. Slavin (2016: 55) mengatakan bahwa strategi pembelajaran STAD merupakan salah satu strategi pembelajaran kooperatif yang paling sederhana, dan menekankan aktitivitas serta interaksi diantara siswa. Keterlibatan siswa secara aktif dalam pembelajaran matematika sangat diperlukan, sehingga pembelajaran lebih bermakna dan matematika tidak lagi dianggap sulit.

Selain menggunakan model STAD dapat juga digunakan model NHT yang merupakan bagian dari model pembelajaran kooperatif untuk meningkatkan hasil belajar siswa. Menurut Huda (2014: 203) Strategi pembelajaran NHT adalah strategi yang memberi kesempatan siswa untuk saling berbagi pendapat dalam sebuah kelompok kecil dimana setiap anggota kelompok mendapatkan nomor yang berbeda-beda.

Model kooperatif tipe STAD dan NHT memiliki persamaan dimana kedua model ini sama-sama membagi siswa menjdai beberapa kelompok dan siswa saling bekerjasama dengan kelompoknya. Rendahnya hasil belajar siswa dalam pokok bahasan operasi hitung pecahan disebabkan juga karena siswa kurang mampu mengkongkritkan konsep yang dijelaskan oleh guru sehingga menyebabkan siswa mengalami kesulitan dalam penguasaan konsep. Untuk mempermudah penyampaian materi ini diperlukan model pembelajaran yang memungkinkan siswa untuk saling berbagi wawasan, informasi, dan konsep pemikiran masing-masing siswa. Selain strategi pembelajaran, kemampuan komunikasi matematis juga sangat berperan dalam keberhasilan proses pembelajaran. Menurut Susanto (2012: 213) komunikasi matematis dapat diartikan sebagai suatu peristiwa dialog atau saling hubungan yang terjadi dilingkungan kelas, dimana terjadi pengalihan pesan, dan pesan yang dialihkan berisikan tentang materi matematika yang dipelajari siswa, misalnya berupa konsep, rumus, atau penyelesaian masalah.Perbedaan kemampuan komunikasi matematis yang dimiliki setiap siswa juga berperan dalam menentukan hasil belajar matematika siswa.

Dari penelitian skripsi sebelumnya yang dilakukan oleh Titi Nurhalimah (2008) yang berjudul "Penerapan Model Pembelajaran Kooperatif Tipe STAD dan NHT pada Pelajaran Matematika Pokok Bahasan Himpunan". Memperoleh hasil model pembelajaran NHT lebih baik daripada model pembelajaran STAD dengan hasil rata-rata model NHT meningkat 28,68 sedangkan moel pembelajaran STAD meningkat 28,05. Sedangkan penelitian lain dilakukan oleh Misbahul Ibad (2011) yang berjudul "Eskperimentasi Pembelajaran Matematika Metode Kooperatif Tipe STAD dan NHT ditinjau dari gaya belajar siswa". Diperoleh hasil bahwa penggunaan model pembelajaran tipe NHT lebih unggul dibanding model pembelajaran STAD Berdasarkan uraian diatas peneliti tertarik untuk melakukan penelitian dengan judul "Perbedaan Pengaruh Penggunaan Model Student Teams Achievement Division (STAD) dan Model Numbered Heads Together (NHT) terhadap Hasil Belajar Matematika Kelas V SD”.

\section{KAJIAN PUSTAKA}

Depdiknas mengemukakan matematika diambil dari salah satu kata dalam bahasa latin "mathemata" yang memiliki arti "sesuatu yang dipelajari". Sedangkan dalam bahasa Belanda dikenal dengan sebutan "wiskunde" yang memiliki arti "ilmu pasti". Jadi secara umum dapat diartikan bahwa matematika merupakan salah satu ilmu yang mendasari kehidupan manusia. Sedangkan Sukardjono (2008: 1-2) mendefinisikan matematika adalah cara atau metode berpikir dan bernalar, bahasa lambang yang dapat dipahami oleh semua bangsa berbudaya, seni seperti pada musik penuh dengan simetri, pola, dan irama yang dapat menghibur, alat bagi pembuat peta arsitek, navigator angkasa luar, pembuat mesin, dan akuntan. Lebih lanjut Ismail dalam Ali Hamzah (2014: 48) mendefinisikan hakikat matematika adalah ilmu yang membahas angka-angka dan perhitungannya, membahas masalah-masalah numerik, mengenai kuantitas dan besaran, mempelajari hubungan pola, bentuk dan struktur, sarana berpikir, kumpulan sistem, struktur dan alat. Dengan demikian dapat disimpulkan bahwa matematika adalah ilmu deduktif yang mempelajari struktur dan pola yang terorganisasi dan saling berhubungan satu sama lain. 
Dalam hal ini berarti konsep-konsep matematika tersusun secara hirarkis yaitu konsep baru terbentuk karena ada pemahaman terhadap konsep sebelumnya.

\section{Pembelajaran Kooperatif}

Rusman (2011: 203) menyebutkan bahwa pembelajaran kooperatif yaitu strategi pembelajaran yang melibatkan partisipasi siswa dalam satu kelompok kecil untuk saling berinteraksi dalam sistem belajar yang kooperatif, siswa belajar bekerjasama dengan anggota lainnya. Dalam model ini siswa memiliki dua tanggung jawab, yaitu mereka belajar untuk dirinya sendiri dan membantu sesama anggota kelompok untuk belajar. Siswa belajar bersama dalam sebuah anggota kelompok untuk belajar. Siswa belajar bersama dalam sebuah kelompok kecil dan mereka dapat melakukannya seorang diri. Sedangkan pembelajaran kooperatif menurut Anita Lie dalam Isjoni (2014: 16) yaitu sistem pembelajaran yang memberi kesempatan kepada peserta didik untuk bekerjasama dengan siswa lain dalam tugas-tugas yang terstruktur. Lebih jauh dikatakan bahwa Pembelajaran kooperatif hanya berjalan kalau sudah terbentuk suatu kelompok atau suatu tim yang di dalamnya siswa bekerja secara terarah untuk mencapai tujuan yang sidah ditentukan dengan jumlah anggota kelompok pada umumnya terditi dari $4-6$ orang saja.

Slavin (2016: 4) menyebutkan pembelajaran kooperatif merujuk pada berbagai macam metode pengajaran dimana para siswa bekerja dalam kelompok-kelompok kecil untuk saling membantu satu sama lainnya dalam mempelajari materi pelajaran. Cara belajar kooperatif jarang sekali menggantikan pengajaran yang di berikan oleh guru, tetapi lebih seringnya menggantikan pengaturan tempat duduk yang individual, cara belajar individual, dan dorongan yang individual. Lebih lanjut pendapat Djahiri dalam Isjoni (2014: 19) menyebutkan pembelajaran kooperatif sebagai pembelajaran kelompok kooperatif yang menuntut diterapkannya pendekatan belajar yang siswa sentris, humanistik, dan demokratis yang disesuaikan dengan kemampuan siswa dan lingkungan belajarnya. Pembelajaran kooperatif dapat dirumuskan sebagai kegiatan pembelajaran kelompok yang terarah, terpadu, efektif-efisien, ke arah mencari atau mengkaji sesuatu melalui proses kerjasama dan saling membantu sehingga tercapai proses dan hasil belajar yang produktif.

Dari pendapat di atas dapat disimpulkan bahwa pembelajaran kooperatif adalah model pembelajaran yang memberikan kesempatan kepada peserta didik untuk bekerja sama dengan peserta didik lainnya dalam menyelesaikan tugas-tugas yang diberikan oleh guru untuk mencapai proses dan hasil belajar yang produktif secara terarah, terpadu dan efektif-efisien.

\section{Student Teams Achievement Division (STAD)}

Menurut Karuru (2003: 791-792) menjelaskan bahwa model pembelajaran kooperatif tipe Student Teams Achievement Division (STAD) dicirikan oleh suatu struktur tugas, tujuan, dan penghargaan kooperatif. Siswa bekerja sama dalam situasi semangat pembelajaran kooperatif seperti membutuhkan kerja sama untuk mencapai tujuan bersama dan mengkoordinasikan usahanya dalam menyelesaikan tugas. Sedangkan Slavin (2016: 214) mengemukakan bahwa gagasan utama di belakang Student Teams Achievement Division (STAD) adalah memacu siswa agar saling mendorong dan membantu satu sama lain untuk menguasai keterampilan yang diajarkan guru. Jika siswa menginginkan kelompok memperoleh hadiah, mereka harus membantu teman sekelompok mereka dalam mempelajari pelajaran. Mereka harus mendorong teman sekelompok untuk melakukan yang berharga dan menyenangkan. Jadi, dapat disimpulkan bahwa model Student Teams Achievement Division (STAD) adalah suatu model atau strategi yang ada di dalam pembelajaran kooperatif yang mengelompokkan 4-5 orang ke dalam satu kelompok yang berbeda kemampuan belajarnya, jenis kelamin, maupun sukunya.

Miftahul Huda (2015: 202) memaparkan bahwa langkah - langkah pembelajaran Kooperatif Student Teams Achievement Division (STAD) adalah sebagai berikut: 1) Penyampaian tujuan dan motivasi; menyampaikan tujuan pelajaran yang ingin dicapai pada pembelajaran tersebut dan memotivasi siswa untuk belajar, 2) Pembagian kelompok; siswa dibagi ke dalam beberapa kelompok, dimana setiap kelompoknya terdiri dari 4-5 siswa yang memprioritaskan keragaman kelas dalam hasil akademik, jenis kelamin, suku ras, 3) Presentasi dari guru; guru menyampaikan materi pelajaran dengan terlebih dahulu 
menjelaskan tujuan pelajaran yang ingin dicapai pada pertemuan tersebut serta pentingnya pokok bahasan tersebut dipelajari. Guru memberi motivasi siswa agar dapat belajar dengan aktif dan kreatif, 4) Kegiatan belajar dalam tim (kerja tim); Siswa belajar dalam kelompok yang telah dibentuk. Guru menyiapkan lembaran kerja sebagai pedoman bagi kerja kelompok, sehingga semua anggota menguasai dan masingmasing memberikan kontribusi. Selama tim bekerja, guru melakukan pengamatan, memberikan bimbingan, dorongan dan bantuan bila diperlukan. Kerja tim ini merupakam ciri terpenting dari model Student Team Achievement Division (STAD), 5) Kuis (evaluasi); guru mengevaluasi hasil belajar melalui pemberian kuis tentang materi yang dipelajari dan juga melakukan penilaian terhadap presentasi hasil kerja masing-masing kelompok. Siswa diberikan kursi secara individual dan tidak dibenarkan bekerja sama. Ini dilakukan untuk menjamin agar siswa secara individu bertanggung jawab kepada diri sendiri dalam memahami bahan ajar tersebut. Guru menetapkan skor batas penguasaan untuk setiap soal, dan 6) Penghargaan hasil belajar siswa; setelah pelaksanaan kuis, guru memeriksa hasil kerja siswa dan diberikan angka dengan rentang 0-100. Selanjutnya pemberian penghargaan atas keberhasilan kelompok dapat dilakukan oleh guru.

\section{Numbered Heads Together (NHT)}

Model Number Heads Together (NHT) mengacu pada belajar kelompok siswa. Masing-masing anggota memiliki bagian tugas (pertanyaan) dengan nomer yang berbeda-beda. Pembelajaran Model Number Heads Together (NHT) ini dikembangkan oleh Spenser Kagan pada tahun 1993. Dalam kegiatan pembelajarannya setiap siswa mendapatkan kesempatan yang sama untuk menunjang timnya guna memperoleh nilai yang maksimal sehingga termotivasi untuk belajar. Setiap diri individu merasa mendapat tugas dan tanggung jawab sehingga tujuan pembelajaran dapat tercapai dengan baik. Dalam pembelajaran ini tidak ada pemisahan antara siswa yang satu dan siswa yang lain dalam satu kelompok untuk saling memberi dan menerima antara satu dengan yang lain (Shoimin, 2014: 51-52).

Langkah-langkah pembelajaran model NHT (Shoimin, 2014: 108) adalah sebagai berikut:

a. Siswa dibagi dalam kelompok. Setiap siswa dalam kelompok mendapat nomor.

b. Guru memberikan tugas dan masing-masing kelompok mengerjakannya.

c. Kelompok mendiskusikan jawaban yang benar dan memastikan tiap anggota kelompok dapat mengerjakannya/mengetahui jawabannya dengan baik.

d. Guru memanggil salah satu nomor siswa dan nomor yang dipanggil keluar dari kelompoknya melaporkan atau menjelaskan hasil kerja sama mereka.

e. Tanggapan dengan teman yang lain, kemudian guru menunjuk kelompok yang lain.

f. Kesimpulan

\section{Hasil Belajar}

Hasil belajar menurut Nana Sudjana (2005: 3) adalah perubahan tingkah laku siswa setelah menyelesaikan pembelajaran. Perubahan tingkah laku ini lebih luas mencakup bidang kognitif, afektif, dan psikomotor. Hasil belajar ini dapat dilihat dari penilaian hasil belajar yang di peroleh masing-masing siswa. Penilaian hasil belajar itu sendiri adalah upaya memberi nilai terhadap kegiatan belajar-mengajar yang telah dilakukan oleh siswa dan guru dalam mencapai tujuan-tujuan pembelajaran yang telah direncanakan. Hamalik (2006: 30) mengatakan, hasil belajar adalah apabila seseorang telah belajar akan terjadi perubahan tingkah laku pada orang tersebut, misalnya dari tidak tahu menjadi tahu dan dari yang tidak bisa menjadi bisa. Sedangkan menurut Soedjioarto mengatakan hasil belajar adalah perubahan perilaku siswa akibat belajar. Perubahan perilaku disebabkan karena siswa mencapai penguasaan atas sejumlah bahan yang diberikan dalam proses belajar mengajar.Pencapaian itu didasarkan atas tujuan pengajaran yang sudah ditetapkan.

Dari ketiga pendapat ahli diatas tentang hasil belajar, sehingga dapat disimpulkan bahwa hasil belajar adalah interaksi belajar dan mengajar yang menimbulkan perubahan tingkah laku pada siswa. Hasil belajar ini dapat mencakup 3 aspek yaitu kognitif (pengetahuan), afektif (sikap), dan psikomotorik 
(keterampilan). Penelitian ini lebih mengambil pada kemampuan kognitif, penilaian yang sering dilakukan guru untuk mengukur seberapa besar pengetahuan yang didapat siswa setelah guru selesai menyampaikan materi pembelajaran. Hasil dari aspek kognitif ini juga dapat dijadikan sebagai tolak ukur guru dalam menyampaikan materi apakah sudah baik atau tidak model yang dipilih.

\section{METODE PENELITIAN}

Jenis penelitian yang digunakan dalam penelitian ini adalah penelitian eksperimen semu (quasi eksperimental research). Eksperimen semu ini merupakan pengembangan dari penelitian eksperimen sungguhan (true eksperimental research). Penelitian eksperimen semu ini menggunakan rancangan "Pretest Posttest Yang Tak Ekuivalen" menurut John W Best dalam buku "Research In Education"yang disunting oleh Sanapiah Fasial dalam buku yang berjudul "Metodologi Penelitian dalam Pendidikan" mengemukakan bahwa desain penelitian Pretest Posttest Yang Tak Ekuivalen merupakan rancangan penelitian yang menggunakan kelas-kelas yang sudah ada baik untuk kelompok eksperimen 1 maupun kelompok eksperimen 2. Pada desain penelitian Pretest Posttest Yang Tak Ekuivalen peneliti dapat menemukan pengambilan sampel melalui kelas-kelas yang sudah ada, tidak perlu melakukan random sampling.

Penelitian ini dilakukan di SD Negeri Sumberejo 01 dan SD Negeri Sumberejo 02. Pada kelas V SD Negeri Sumberejo 01 sebagai kelompok eksperimen 1 sedangkan kelas V SD Negeri Sumberejo 02 sebagai kelompok eksperimen 2. Pada kelas eksperimen 1 diterapkan model Student Teams Achievement Division (STAD), sedangkan kelas eksperimen 2 diterapkan model Numbered Heads Together (NHT) dengan jumlah total sebanyak 38 siswa. Teknik pengumpulan data adalah cara yang ditempuh dan digunakan untuk mencari dan mengumpulkan data, keterangan, persyaratan dan sebagainya yang diatur agar sifatnya sesuai dengan apa adanya tanpa ada penafsiran dan perubahan. Data yang diperoleh dalam penelitian ini berupa data hasil belajar matematiak SD kelas V. Untuk memperoleh data tersebut peneliti menggunakan teknis tes dan non tes sebagai teknis pengumpulan data. Teknik tes yang digunakan dalam penelitian ini adalah pilihan ganda yang terdiri dari pretest dilakukan sebelum penggunaan model pembelajaran kooperatif tipe STAD dan posttest dilakukan setelah menggunakan model pembelajaran kooperatif tipe STAD dan dibandingkan dengan nilai pretest yang dilakukan sebelum menggunakan model pembelajaran kooperatif tipe NHT dan posttest dilakukan setelah menggunakan model pembelajaran kooperatif tipe NHT. Sedangkan teknik non tes dilakukan untuk mengukur aktifitas siswa.

Jenis penelitian yang digunakan dalam penelitian ini adalah penelitian eksperimen semu (quasi eksperimental research) yang menggunakan rancangan "Pretest Posttest Yang Tak Ekuivalen" menurut John W Best. Penelitian ini dilakukan pada siswa kelas V SD "X" sebagai kelompok eksperimen 1 sedangkan siswa kelas V SD "Y" sebagai kelompok eksperimen 2. Pada kelas eksperimen 1 diterapkan model Student Teams Achievement Division (STAD), sedangkan kelas eksperimen 2 diterapkan model Numbered Heads Together (NHT) dengan jumlah total 2 kelompok sebanyak 38 siswa. Teknik pengumpulan data menggunakan teknis tes dan non tes. Teknik Analisis Data menggunakan independent sample t test dengan bantuan aplikasi SPSS versi 16.0.

\section{HASIL DAN PEMBAHASAN}

Rendahnya kemampuan siswa dalam menyelesaikan persoalan matematika merupakan hal yang berpengaruh pada rendahnya kualitas pembelajaran matematika. Pada umumnya proses pembelajaran yang dilakukan guru sering menggunakan metode otoriter, metode yang membuat siswa tidak gembira menghadapi pelajaran. Hal ini ditunjukkan dengan hasil nilai pretest siswa pada kelas eksperimen 1 menunjukkan dari 19 siswa masih terdapat 5 siswa yang belum memenuhi KKM. Sedangkan pada kelas eksperimen 2 menunjukkan dari 19 siswa terdapat 12 siswa yang belum memenuhi KKM. 
Perbedaan Pengaruh Model Student Teams Achievement Division (STAD) Dan Numbered Heads Together (NHT) Terhadap Hasil Belajar Matematika Siswa Kelas V SD (Nur Halimah, Sumardjono)

Tabel 1. Perbandingan hasil pretest kelas eksperimen 1 dan eksperimen 2

\begin{tabular}{lccc}
\hline No & Kategori Soal & $\begin{array}{c}\text { Frekuensi Kelas } \\
\text { eksperimen 1 }\end{array}$ & $\begin{array}{c}\text { Frekuensi Kelas } \\
\text { eksperimen 2 }\end{array}$ \\
\hline 1. & Sangat Tinggi & 6 & 3 \\
2. & Tinggi & 8 & 4 \\
3. & Rendah & 3 & 9 \\
4. & Sangat Rendah & 2 & 3 \\
\hline
\end{tabular}

Pembelajaran dengan menggunakan model Student Teams Achievement Division (STAD) dan Numbered Heads Together (NHT)

Setelah dilakukan pembelajaran pada mata pelajaran matematika SD kelas V materi operasi hitung pecahan dan hasil daripada pembelajaran dengan menggunakan model Student Teams Achievement Division (STAD) pada kelas eksperimen 1 dapat dilihat pada tabel 2 dibawah ini sedangkan hasil pembelajaran dengan menggunakan model Numbered Heads Together (NHT) pada kelas eksperimen dapat dilihat pada tabel 3, maka diperoleh hasil yang lebih meningkat dimana pada kelas eksperimen 1 nilai tertinggi adalah 95 dan nilai terendah adalah 60 dengan nilai rata-rata 77,89. Sedangkan pada kelas eksperimen 2 nilai tertinggi adalah 100 dan nilai terendah adalah 65 dengan nilai rata-rata 85,53 .

\section{Histogram}

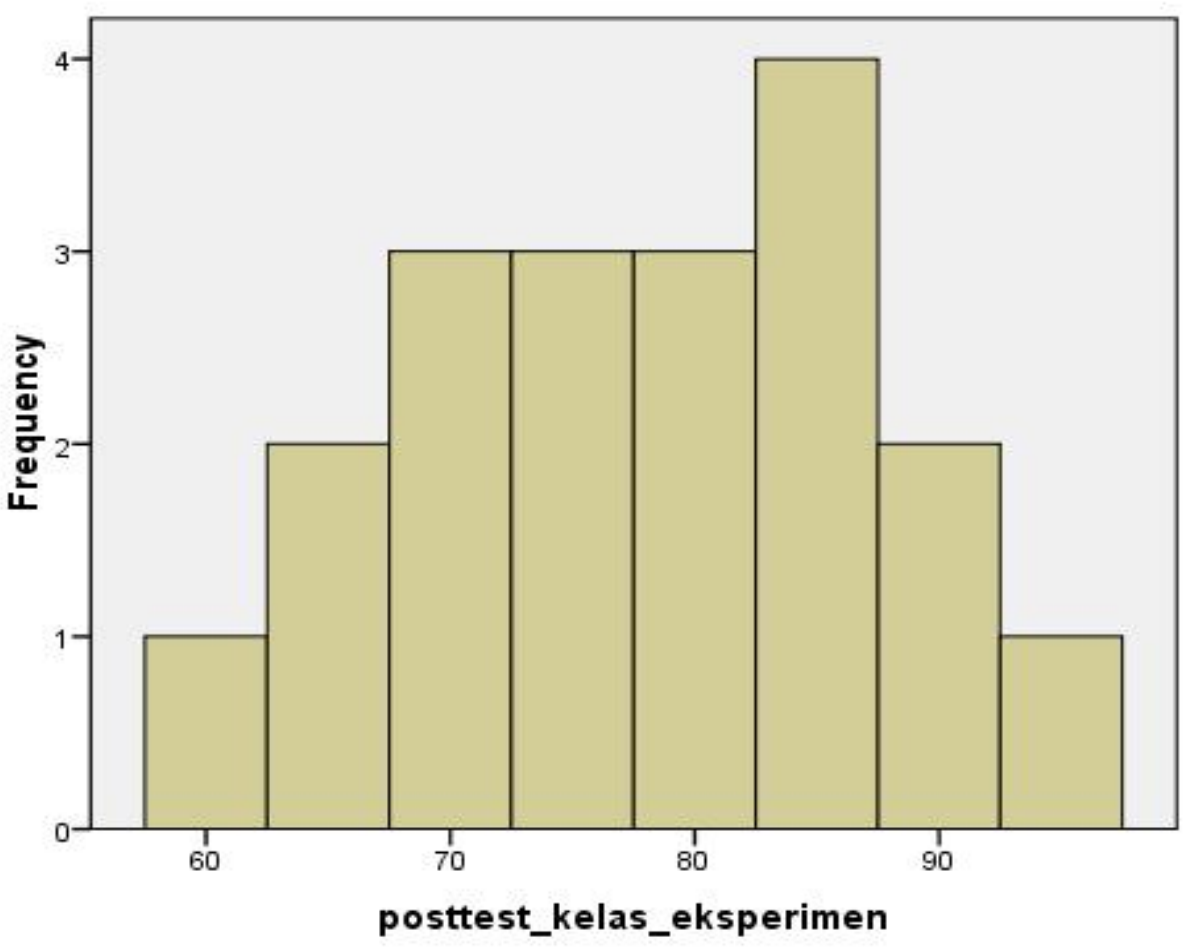

Mean $=77.89$ Std. Dev. $=9.62$ $N=19$

Gambar 1. Hasil posttest kelas eksperimen 1 


\section{Histogram}

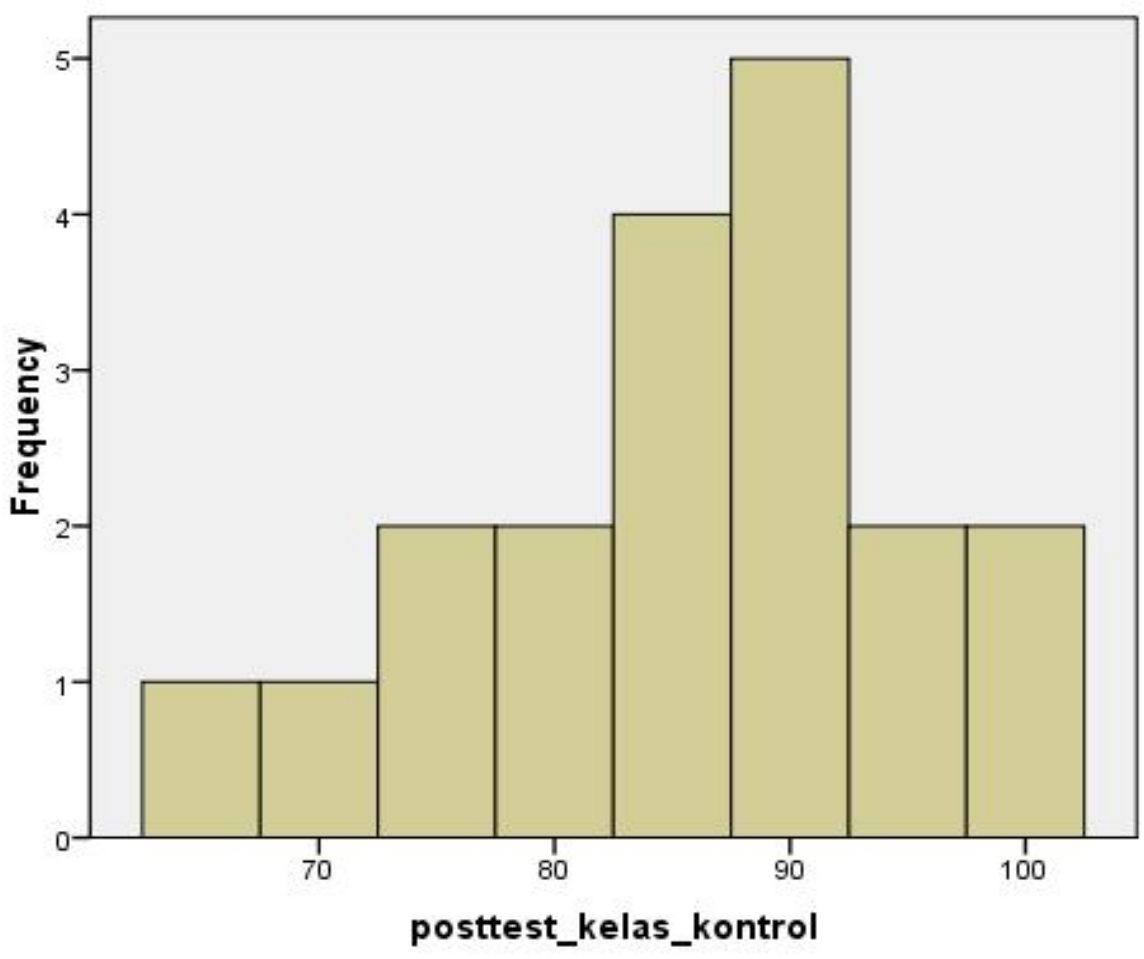

Mean $=85.53$ Std. Dev. $=9.559$ $N=19$

Gambar 2. Hasil posttest kelas eksperimen 2

Hasil uji t tes nilai signifikansi adalah 0,019 < 0,05, maka Ho ditolak Ha diterima. Jadi dapat disimpulkan "Terdapat perbedaan pengaruh yang signifikan antara penggunaan model Student Teams Achievement Division (STAD) dengan model Numbered Heads Together (NHT) terhadap hasil belajar matematika kelas V SD". Berdasarkan data tersebut di atas menunjukkan bahwa model Number Head Together (NHT) lebih baik digunakan dari pada model pembelajaran Student Team Achievement Division (STAD) pada mata pelajaran matematika siswa kelas V SD. Penelitian ini sejalan dengan penelitian yang dilakukan oleh Kusumawati (2014: 251) yang mengatakan bahwa perlakuan pembelajaran dengan model NHT memberikan dampak pada hasil belajar yang berbeda dan lebih tinggi daripada model pembelajaran STAD. Penelitian lain juga pernah dilakukan oleh Nurhalimah (2008) dimana melalui penerapan strategi NHT, partisipasi yang ditunjukkan oleh setiap siswa dan kelompok penyaji sangat tinggi, sehingga dapat mendorong siswa untuk belajar mengidentifikasi dan menyelesaikan tugas masing-masing pada pembahasan tertentu. Selain itu, strategi NHT memiliki satu kelebihan lain yang tidak dimiliki oleh strategi STAD yaitu siswa dilibatkan secara aktif dalam diskusi dalam kelompok dan luar kelompok, mengembangkan sikap kepemimpinan siswa, meningkatkan rasa percaya diri dan sikap ingin tahu siswa, serta mengembangkan keterampilan untuk masa depan. Selain itu juga sejalan dengan hasil penelitian Hanifah Kusumawati dan Mawardi (2016) yang menemukan bahwa perlakuan pembelajaran dengan model NHT memberikan dampak pada hasil belajar yang berbeda dan lebih tinggi daripada model pembelajaran STAD.

Penelitian ini bertolak belakang dengan penelitian yang dilakukan oleh Herlina (2012: 4) yang menyatakan bahwa rata-rata hasil belajar biologi antara siswa yang belajar dengan menggunakan metode kooperatif tipe STAD lebih tinggi dari rata-rata hasil belajar dengan menggunakan metode kooperatif tipe 
NHT pada pokok bahasan organisasi kehidupan karena adanya peran Aktif tutor sebaya untuk lebih meningkatkan keberhasilan kelompok. Penelitian lain yang bertolak belakang dengan hasil penelitian saya pernah dilakukan oleh Nita Idriastuti (2016: 7) yang mengatakan bahwa tidak terdapat perbedaan yang signifikan pengaruh strategi STAD dan NHT terhadap hasil belajar matematika siswa. Baik strategi STAD ataupun NHT memiliki pengaruh yang sama terhadap hasil belajar siswa, meskipun nilai yang diperoleh memiliki sedikit perbedaan. Strategi STAD dan NHT mempunyai beberapa kelebihan yang hampir sama, antara lain; melatih kerjasama siswa dalam berdiskusi kelompok, setiap anggota bertanggung jawab terhadap anggota lainnya dalam satu kelompok dan siswa dilibatkan secara aktif dalam berpikir. Penelitian lain juga pernah dilakukan oleh Eldiana (2014: 6) dimana strategi STAD, NHT maupun Jigsaw merupakan strategi pembelajaran yang berpusat pada siswa dengan pendekatan kooperatif. Strategi yang termasuk dalam pembelajaran kooperatif baik STAD, NHT, Jigsaw dan strategistrategi kooperatif lainnya memiliki dasar pembelajaran yang sama pula yaitu dengan cara diskusi atau kerjasama kelompok. Melalui cara atau strategi pembelajaran yang sama dari startegi-strategi tersebut, maka pengaruh yang diberikan pada hasil belajar siswa juga tidak akan memiliki perbedaan yang jauh atau bahkan sama.

\section{SIMPULAN DAN SARAN}

Berdasarkan hasil analisis dan pembahasan, maka dapat ditarik kesimpulan bahwa ada perbedaan yang signifikan antara model kooperatif tipe Student Teams Achievement Division (STAD) dan Numbered Heads Together (NHT) terhadap hasil belajar matematika siswa kelas V SD. Hal ini ditunjukkan oleh hasil uji hipotesis dengan menggunakan kriteria signifikan probabilitas sig (2 tailed), dari uji t/ uji beda menunjukkan sig sebesar 0,019 yang berarti kurang dari 0,05. Dengan kata lain penelitian ini menunjukkan bahwa terdapat perbedaan pengaruh yang signifikan pada hasil belajar matematika pada siswa kelas V SD "X" sebagai kelas eksperimen 1 dan SD "Y" sebagai kelas eksperimen 2. Perbedaan hasil belajar matematika yang signifikan tersebut didukung dengan perbedaan rerata dua sampel penelitian, dimana rerata hasil belajar pada penerapan model pembelajaran STAD sebesar 77,89, sedangkan rerata hasil belajar pada penerapan model pembelajaran NHT sebesar 85,53. Perbedaan pengaruh itu nampak pada perilaku belajar siswa yang ditunjukkan siswa saat bekerja kelompok yaitu pada kelas eksperimen 2 lebih aktif dan tertib dalam mengerjakan soal, terlebih kelas eksperimen 2 mewajibkan setiap individu dapat mengerjakan soal sehingga masing-masing anggota memahami cara mengerjakan soal, sedangkan kelas eksperimen 1 masih terdapat siswa yang bermain-main sendiri ketika berdiskusi kelompok. Maka dilihat dari nilai posttest dan ketuntasan yang diperoleh oleh masing-masing siswa menunjukkan bahwa kelas eksperimen 2 mimiliki nilai yang lebih tinggi dan semua siswa mencapai nilai ketuntasan.

Berdasarkan simpulan di atas, beberapa hal yang dapat disarankan sebagai berikut: (1) kepada guru agar saat menggunakan model NHT disarankan agar guru lebih memberi peluang untuk siswa yang butuh motivasi belajar agar mendapat pelatihan yang lebih banyak. (2) kepada siswa lebih memperhatikan penjelasan guru di kelas dan pada saat siswa bekerja dalam kelompok setiap anggota harus berpartisipasi dalam mengerjakan soal, siswa seharusnya memiliki semangat lebih dalam belajar baik menggunakan model STAD (Students Teams Achievement Division) maupun NHT (Numbered Heads Together) agar hasil belajar siswa bisa meningkat. (3) kepada peneliti lanjut untuk mempersiapkan instrumen dan perlengkapan penelitian dengan baik agar penelitian dapat berjalan dengan baik dan sesuai dengan yang diharapkan. Berkaitan dengan waktu, alangkah lebih baik lagi jika dalam penelitian dilakukan sebanyak 3

kali pertemuan dalam satu kelompok. Serta dibutuhkan media yang lebih sesuai dengan usia dan tingkat kognitif siswa. Contohnya untuk siswa kelas V masih menggunakan media yang kongkrit. 
Scholaria: Jurnal Pendidikan dan Kebudayaan, Vol 7 No 3, September 2017: 267 - 275

\section{DAFTAR PUSTAKA}

Eldiana. 2014. Studi Komparasi Hasil Belajar Siswa dengan Menerapkan Model Kooperatif Tipe NHT dan Jigsaw pada Mata Pelajaran Matematika Kelas 5 SD N 3 Bengkulu. Skripsi. Univeritas Bengkulu.

Hamalik, Oemar. 2011. Proses Belajar Mengajar. Bandung: Bumi Aksara.

Hamzah, Ali.2014. Perencanaan dan Strategi Pembelajaran Matematika. Rajawali Pers.

Hanifah Kusumawati dan Mawardi, 2016. Perbedaan Penerapan Model Pembelajaran Kooperatif Tipe NHT dan STAD Ditinjau Dari Hasil Belajar Siswa. Scholaria Jurnal Pendidikan dan Kebudayaan. Vol 6, No 3 (2016)

Herlina. 2012. Perbandingan Pembelajaran Kooperatif Tipe STAD dan NHT terhadap Hasil Belajar Biologi. Universitas Muhammadiyah Metro.

Huda, Miftahul. 2014. Model-Model Pengajaran dan Pembelajaran. Yogyakarta: Pustaka Belajar

Isjoni. 2014. Cooperative Leraning. Bandung: Alfabeta

Karuru, Predy. 2003. Penerapan Pendekatan Ketrampilan Proses dalam Setting Pembelajaran Kooperatif STAD untuk Meningkatkan Kualitas Pembelajaran IPA SLTP.

Kusumawati, H. 2012. Perbedaan Penerapan Model Pembelajaran Kooperatif Tipe NHT dan STAD Ditinjau dari Hasil Belajar Siswa. Salatiga: Universitas Kristen Satya Wacana.

Nita Indriastuti. 2016. Studi Komparasi Strategi Student Teams Achievement Division (STAD) dan Numbered Heads Together (NHT) terhadap Hasil Belajar Matematika Siswa Kelas IV SDN 1 Siswodipuran Boyolali Tahun Ajaran 2015/2016. Universitas Muhammadiyah Surakarta.

Nurhalimah, Titi. (2008). Penerapan Model Pembelajaran Kooperatif Tipe STAD dan NHT pada Pelajaran Matematika Pokok Bahasan Himpunan. Skripsi. Universitas Muhammadiyah Surakarta.

Rusman. 2011. Model - Model Pembelajaran. Jakarta. Rajawali Pers

Shoimin, Aris. 2014. Model Pembelajaran Inovatif dalam Kurikulum. Yogyakarta: Ar-ruzz Media.

Slavin, E. Robert. 2016. Cooperative Learning Teori, Riset dan Praktik. Bandung: Nusa Media

Sudjana, Nana. 2012. Penilaian Hasil Proses Belajar Mengajar. Bandung: Remaja Rosdakarya Algesindo.

Sukardjono. 2008. Landasan dan Arah Pendidikan Nasional Kita. Kompasiana.

Susanto, Ahmad. 2013. Teori Belajar dan Pembelajaran di Sekolah Dasar. Jakarta: Kencana

\section{PROFIL SINGKAT}

Nur Halimah lahir di Kab. Semarang 19 September 1994. Merupakan mahasiswi S1 PGSD di Universitas Kristen Satya Wacana. Telah melakukan penelitian Tugas Akhir dan sedang menuntaskan Tugas Akhirnya. 